\title{
Effect of Allium fistulosum Extract on Ralstonia solanacearum Populations and Tomato Bacterial Wilt
}

Péninna Deberdt, Benjamin Perrin, and Régine Coranson-Beaudu, CIRAD, UPR HORTSYS, Pôle de Recherche Agroenvironnementale de Martinique (PRAM), Le Lamentin, Martinique, France, 97285; Pierre-François Duyck, CIRAD, UPR "Systèmes de culture bananiers", PRAM; and Emmanuel Wicker, CIRAD, UMR PVBMT, Saint Pierre, La Réunion, France, 97410

\begin{abstract}
Deberdt, P., Perrin, B., Coranson-Beaudu, R., Duyck, P.-F., and Wicker, E. 2012. Effect of Allium fistulosum extract on Ralstonia solanacearum populations and tomato bacterial wilt. Plant Dis. 96:687-692.

To control bacterial wilt (Ralstonia solanacearum, phylotype IIB/4NPB), the antimicrobial effect of Allium fistulosum aqueous extract was assessed as a preplant soil treatment. Three concentrations of extract $(100,50$, and $25 \%, 1: 1$ [wt/vol]) were evaluated by in vitro inhibition assay and in vivo experiments in a growth chamber. In vitro, A. fistulosum (100 and 50\%) suppressed growth of $R$. solanacearum. Preplant treatment of the soil with A. fistulosum extract significantly reduced the $R$. solanacearum populations. No pathogen was detected

in the soil after treatment with $100 \%$ concentrated extract from the third day after application until the end of the experiment. A. fistulosum also significantly reduced the incidence of tomato bacterial wilt. In the untreated control, the disease affected $61 \%$ of the plants whereas, with 100 and 50\% extracts, only 6 and $14 \%$ of the plants, respectively, were affected. These results suggest that A. fistulosum extracts could be used in biocontrol-based management strategies for bacterial wilt of tomato.
\end{abstract}

Bacterial wilt caused by Ralstonia solanacearum occurs worldwide, affects hundreds of plant species, and is among the most widespread plant diseases in tropical and subtropical regions (17), including the West Indies. It affects both cash and subsistence crops. In Martinique (French West Indies), bacterial wilt is a major disease of vegetable crops, particularly of the most common crop, tomato, which has been affected by $R$. solanacearum phylotype I and IIA since the 1960s (28). After 1999, the situation changed with the emergence of new strains of $R$. solanacearum (positioned in phylotype IIB, sequevar 4NPB) whose hosts include members of the families Solanaceae, Cucurbitaceae, and Anthurium (36,37).

Despite the efforts of several research teams, the efficiency of current strategies for management of bacterial wilt is still limited. Bacterial wilt is a soilborne systemic disease that cannot be efficiently controlled through foliar application of copper pesticides, as reported by M. T. Momol (19). Although host resistance is the most effective control option, it is difficult to obtain cultivars with stable resistance across tropical locations given the high temperatures and humidity that prevail (14). Recent studies reported that the emerging $R$. solanacearum populations affect major resistant sources $(23,35)$, making its control even more difficult. Hence, development of biorational soil treatments for effective management of bacterial wilt is highly desirable.

Natural plant products are important sources of new agrochemicals for the control of some plant diseases $(1,8,16,18,21,30)$. Plant extracts are potentially environmentally safe alternatives and, thus, possible components of integrated pest and disease management programs. Several essential oils and their components have been reported to have a bactericidal effect against $R$. solanacearum; field experiments using thymol and palmarosa oil for preplant soil fumigation showed that it was effective in reducing the incidence of tomato bacterial wilt and resulted in higher yields (18). The use of plant essential oils as biofumigants has also been examined as a

Corresponding author: P. Deberdt, E-mail: peninna.deberdt@cirad.fr

Accepted for publication 17 November 2011.

http://dx.doi.org/10.1094/PDIS-07-11-0601

(C) 2012 The American Phytopathological Society component in integrated disease management systems (19). Recently, palmarosa and lemongrass oils were shown to reduce the growth of $R$. solanacearum race 4 (phylotype I) in potting medium and the incidence of bacterial wilt of edible ginger (25). Other authors reported the potential of aqueous extracts of Hibiscus sabdariffa, Punica granatum, and Eucalyptus globulus to protect potato plants against bacterial wilt caused by $R$. solanacearum under greenhouse and field conditions (16).

Allium genus plants have been used since antiquity in traditional medicine and for their antimicrobial properties (15). The properties of Allium spp. are attributed to sulfur volatiles produced during degradation of Allium tissues (3). The most widely studied substance, allicin (diallylthiosulfinate), present in extract of Allium sativum, was shown to have significant antibiosis effects against a wide range of plant-pathogenic bacteria and fungi $(12,32)$. Recently, Balestra et al. (4) demonstrated that A. sativum extract was highly effective in protecting tomato plants against three major disease-causing bacteria: Pseudomonas syringae pv. tomato, Xanthomonas vesicatoria and Clavibacter michiganensis subsp. michiganensis. Other studies showed that $A$. sativum extract reduced $R$. solanacearum populations in in vitro tests and tomato bacterial wilt incidence when applied to soil (2). Hence, we hypothesized that A. fistulosum, which is widely cultivated in Martinique and is well adapted to local soil and climatic conditions, could effectively reduce soil populations of $R$. solanacearum and reduce bacterial wilt incidence on tomato.

The main objective of this study was to evaluate the in vitro and in vivo antibacterial effects of aqueous extract of A. fistulosum on the density of the soil population of $R$. solanacearum and on the incidence of tomato bacterial wilt.

\section{Materials and Methods}

One laboratory test and two growth chamber assays were conducted at the Pôle de Recherche Agro-environnementale de Martinique. Laboratory experiment 1 aimed to evaluate the in vitro antibacterial activity of $A$. fistulosum aqueous extract on the growth of $R$. solanacearum on nutrient agar plates. Experiment 2 aimed to assess the effect of an aqueous extract of A. fistulosum on $R$. solanacearum population density in artificially infested natural soil. Experiment 3 aimed to evaluate the effect of preplant soil treatments with aqueous extracts of $A$. fistulosum on the incidence of bacterial wilt in a susceptible tomato cultivar. 
Bacterial culture and inoculum preparation. All experiments were performed using the highly virulent $R$. solanacearum strain CFBP6783, belonging to the emerging population phylotype IIB/4NPB (36), which was originally isolated from a diseased Heliconia sp. and deposited in the Collection Française de Bactéries Phytopathogènes (CFBP, Angers, France). A single colony of the isolate was grown on casamino acid peptone glucose medium (CPG) (22) for $48 \mathrm{~h}$ at $28^{\circ} \mathrm{C}$. Bacteria were suspended in sterile distilled water, and cell density was adjusted to $10^{8} \mathrm{CFU} / \mathrm{ml}$ using a spectrophotometer (optical density at $600 \mathrm{~nm}$ ).

Plant extracts. Freeze-dried aqueous extracts of A. fistulosum L. ('Ciboule blanche') were used in experiment 1. The extract was obtained from fresh commercial plants (bulbs and leaves) and prepared according to Jourand et al. (20). Due to the high level of variability in concentration of active compounds between organs of Allium plant species (7) and because it is not known which organ extract from A. fistulosum would be most effective, we chose to use an extract including both leaves and bulbs. Dry powder $(1 \mathrm{~g})$ was diluted in $1 \mathrm{ml}$ of sterile distilled water to obtain a final concentration of $100 \%$ (1:1 [wt/vol]). Crude aqueous extract of $A$. fistulosum was used in experiments 2 and 3. This extract was obtained from $100 \mathrm{~g}$ of fresh commercial plants (bulbs and leaves). Plants were washed with running tap water, then with sterile water. Plant materials were cut into small pieces and ground with $100 \mathrm{ml}$ of sterile distilled water $(1: 1[\mathrm{wt} / \mathrm{vol}])$ in a blender for $1 \mathrm{~min}$ at room temperature and filtered through sterile double-layered cheesecloth. Freeze-dried and crude aqueous extracts at a concentration of $100 \%$ were then diluted with sterile distilled water to obtain two additional concentrations of 50 and $25 \%$.

Natural soil. The soil used in these studies was a natural soil obtained from the top layer (first $15 \mathrm{~cm}$, corresponding to the area of the roots of tomato plants) of a field located at the CIRAD station in Rivière Lézarde, Martinique (Nitisol: clay, $86.0 \%$ alloysite; silt, 5.3\%; sand, $10.9 \%$; organtic matter, $4.55 \%$; $\mathrm{pH} 5.5$ ). The soil was sun dried for 4 days and sieved at $5 \mathrm{~mm}$. Preliminary tests showed, that following soil infestation with $R$. solanacearum at $2.5 \times 10^{5}$ CFU/g of dry soil, disease incidence on the 'Heatmaster' reached 97\% within 10 days (data not shown).

Experiment 1, in vitro inhibition assay. The antibacterial in vitro assay was carried out according to the agar-well diffusion method (33). Strain CFBP6783 was used at a concentration of $10^{7}$ and $10^{8} \mathrm{CFU} / \mathrm{ml}$ to obtain useful indications for survival studies in in vivo tests. The agar-well diffusion method was performed on CPG medium. Each bacterial suspension $(200 \mu \mathrm{l})$ was spread on CPG medium in agar plates. Wells were made in nutrient agar plates using the broad end of a sterile Pasteur pipette $(6 \mathrm{~mm}$ in diameter), and A. fistulosum extracts ( $20 \mu \mathrm{l}$ of each concentration tested) were added to each well. Sterile distilled water was used as control. The plates were incubated at $28^{\circ} \mathrm{C}$ for $24 \mathrm{~h}$ and the diameters of inhibition zones were measured in millimeters after the incubation period. The experiments were repeated three times with three replicates in each block. Because there was no block effect, we presented nine replications for each extract concentration and each inoculum concentration for a total of 72 samples.

Experiment 2, population density after soil treatment. This experiment was performed in a growth chamber with an average relative humidity of $80 \%$, in darkness, and a 30 to $26 \pm 2{ }^{\circ} \mathrm{C}$ temperature regime. Plastic bags were filled with $1.5 \mathrm{~kg}$ of dried soil, and $120 \mathrm{ml}$ of sterile water were added to moisten the soil. The soil from each bag was then artificially infested by adding $40 \mathrm{ml}$ of the $R$. solanacearum inoculum solution at $10^{7} \mathrm{CFU} / \mathrm{ml}$ to reach a final estimated population of $2.7 \times 10^{5} \mathrm{CFU} / \mathrm{g}$ of dry soil. Two hours after soil contamination, bacterial populations, including $R$. solanacearum and "no RS bacteria" (bacterial populations other than $R$. solanacearum and growing on semi-selective medium [SMSA] medium), were enumerated using the method described below. Six hours after inoculation, treatments were applied by drenching the soil with $200 \mathrm{ml}$ of $A$. fistulosum aqueous extracts at 100, 50, and $25 \%$ concentrations (three treatments), whereas the same amount of sterile water $(200 \mathrm{ml})$ was used for the untreated control. Bags were then vigorously shaken to homogenize their contents and closed (but not hermetically) to limit the escape of major volatiles and contamination. The bacterial population was enumerated at 3 , $7,10,14,21,28,35,52$, and 59 days after treatment. At each enumeration date, $5 \mathrm{~g}$ of soil from each bag was sampled and suspended in $25 \mathrm{ml}$ of buffered soil dispersion solution $(0.1 \mathrm{M} \mathrm{NaCl}$, $0.01 \%$ sodium dodecyl sulfate, and $0.1 \%$ sodium pyrophosphate; $\mathrm{pH}$ 7.2) (34), shaken at $100 \mathrm{rpm}$ for $30 \mathrm{~min}$ in a mixer-rotator REAX2 (Heidolph; Fisher Scientific Inc.), and left to settle for 5 min. The supernatant $(1 \mathrm{ml})$ was used to start a 10 -fold dilution series (from $10^{-1}$ to $10^{-4}$ ) and $50 \mu \mathrm{l}$ of each dilution was plated on duplicate plates of modified SMSA medium (13). After incubating for 3 days at $28^{\circ} \mathrm{C}, R$. solanacearum colonies and no RS bacteria colonies that appeared on the plates were counted, and the number of viable cells in the soil at the time of sampling was estimated from the count. The $R$. solanacearum colonies isolated from the soil were further confirmed by Pmx-polymerase chain reaction (PCR) and Mmx-PCR analysis as described by Prior and Fegan (27). To enumerate the soilborne population as CFU per gram of dry soil, soil moisture was recorded at each sampling date. Two 10$\mathrm{g}$ samples of soil were removed from each bag and oven dried at $130^{\circ} \mathrm{C}$ for $24 \mathrm{~h}$ to determine soil moisture. For each date and each treatment, the experiments have been repeated five times with two replicates per bag, giving a total of 400 samples.

Experiment 3, disease control. This experiment was performed in a growth chamber, with the climatic conditions and soil described above. Pots ( 0.4 liter) were filled with $400 \mathrm{~g}$ of dry soil, and $50 \mathrm{ml}$ of sterile water was added to each pot to moisten the soil. The soil from each pot was then artificially infested by adding $10 \mathrm{ml}$ of the $R$. solanacearum inoculum solution at $10^{7} \mathrm{CFU} / \mathrm{ml}$ to obtain a final estimated population of $2.5 \times 10^{5} \mathrm{CFU} / \mathrm{g}$ of dry soil. Two hours after inoculation, treatments were applied by drenching the soil with $50 \mathrm{ml}$ of $A$. fistulosum aqueous extracts at 100 and $50 \%$, whereas controls received the same amount of sterile water $(50 \mathrm{ml})$. To detect possible phytotoxicity problems on tomato, two durations of preplant treatment (15 and 30 days) were tested before the tomato plants were transplanted. During these periods (15 and 30 days), the pots were covered with aluminum sheets to limit the escape of volatiles and contamination. Two days before the tomato plants were transplanted, the aluminum sheets were removed to allow excess volatiles to escape. The susceptible tomato Heatmaster (Seminis Seeds) was used to assess the incidence of bacterial wilt disease. One 3-week-old tomato seedling was transplanted in each pot. Bacterial wilt incidence was calculated as the percentage of wilted plants. For each treatment, the experiments have been repeated three times with 12 replicates (individual pots) in each block. Each plant was checked separately three times a week for 4 weeks (total of 2,808 samples).

Wilted tomato plants were first sampled for isolation of $R$. solanacearum on modified SMSA medium. Presumptive colonies of $R$. solanacearum were confirmed by Pmx-PCR and Mmx-PCR analysis as described by Prior and Fegan (27).

At the end of the experiment (4 weeks after transplantation), the presence of $R$. solanacearum on remaining and asymptomatic plants was assessed on the basal part of the stem for the calculation of colonization index.

Statistical analyses. Experiment 1. Diameters of the inhibition zone were analyzed by analysis of covariance as a function of the concentration of extract (covariable), the concentration of the inoculum (factor), and their interaction. Means of inhibition diameters were then compared using Tukey's honestly significant difference test.

Experiment 2. Counts of $R$. solanacearum and no RS bacteria were analyzed using a generalized linear model (GLM) with Poisson error as a function of the concentration of the extract, time after treatment, and interaction between these two variables (fitted as quantitative variables). Differences in deviances ( $\Delta D e v)$ were used to assess the effects of factors when using the GLMs (24). Overdispersion was accounted for using Quasi-Poisson instead of Poisson models in R (11). 
Experiment 3. The incidences of bacterial wilt (percentage of wilted plants) were analyzed using a generalized linear mixedeffects model (GLMM; 6) with a binomial error as a function of the duration of the preplant treatment (factor), the concentration of A. fistulosum extract (quantitative variable), time after transplantation (quantitative variable), and first-order interactions between these three variables. We included "plant identifier" and "block" as crossed (nonhierarchical) random effects. We treated them as random effects because we assumed that they contained unobserved heterogeneity that we could not model, and considered them as pseudo-replication. We used standard model simplification procedures to remove nonsignificant terms from the model (39). The significance of each term was assessed through the change in deviance between models with and without that term. We used the glmer function in the "Ime4" library (5) in the statistical program R 2.12 .1 (29).

\section{Results}

Experiment 1, in vitro inhibition assay. The concentration of the extract $(F=387.6 ; \mathrm{df}=1,68 ; P<0.0001)$, the concentration of the inoculum $(F=7.7 ; \mathrm{df}=1,68 ; P=0.007)$, and their interaction $(F=4.6$; df $=1,68 ; P=0.034)$ all had strong effects on the diameter of inhibition zone.

A. fistulosum extract at concentrations of 50 and $100 \%$ exhibited antimicrobial activity against $R$. solanacearum strain CFBP6783 at both bacterial concentrations $\left(10^{7}\right.$ and $\left.10^{8} \mathrm{CFU} / \mathrm{ml}\right)$ used in vitro (Table 1). The best inhibition effects of the extracts were observed at a bacterial concentration of $10^{7} \mathrm{CFU} / \mathrm{ml}$. Growth of $R$. solanacearum was significantly lower when the concentration of the $A$. fistulosum was 100 rather than $50 \%$, regardless of the bacterial concentration $(P<0.0001)$. At a concentration of $25 \%$, no effects of A. fistulosum were observed on growth of $R$. solanacearum $(P=1)$.

Experiment 2, population density after soil treatment. The concentration of the extract $(\Delta D e v=9038 ;$ df $=1,396 ; P<$ $0.0001)$, time after treatment $(\Delta D e v=89417$; df $=1,396 ; P<$ $0.0001)$, and their interaction $(\Delta D e v=7797$; df $=1,396 ; P<$ 0.0001 ) had strong effects on the population of $R$. solanacearum in soil. The same variables also had significant effects on the population of no RS bacteria (concentration of the extract: $\Delta D e v=$ 1033233, df $=1,396, P<0.0001$; time after treatment: $\Delta D e v=$ 45681, $\mathrm{df}=1,396, P<0.0001$; and their interaction: $\Delta D e v=$ 11176, df $=1,396, P=0.0025)$.

Soil treated with A. fistulosum extract reduced populations of $R$. solanacearum strain CFBP6783 and increased populations of no RS bacteria compared with the untreated control soil over a period of 60 days after soil treatment (Fig. 1). The initial population of $R$. solanacearum in the untreated control was $5.0 \mathrm{log}$ CFU/g of dry soil. The population of $R$. solanacearum in the control remained stable, with similar counts of $R$. solanacearum $(5.0 \mathrm{log} \mathrm{CFU} / \mathrm{g}$ of dry soil) 60 days later (Fig. 1A). The effect of A. fistulosum extract was apparent 3 days after soil treatment. A. fistulosum extract at a concentration of $100 \%$ reduced the population of $R$. solanacearum faster than other concentrations (50 and $25 \%)$ and populations

Table 1. Antibacterial effects of Allium fistulosum extracts on growth of Ralstonia solanacearum phylotype IIB/4NPB on casamino acid peptone glucose medium after $24 \mathrm{~h}$ of incubation at $28^{\circ} \mathrm{C}$

\begin{tabular}{|c|c|c|}
\hline \multirow[b]{2}{*}{ Concentration $(\%)^{\mathrm{z}}$} & \multicolumn{2}{|c|}{$\begin{array}{c}\text { Diameter of inhibition zone (mm) } \\
(\text { means } \pm \text { SE) })^{\mathrm{y}}\end{array}$} \\
\hline & $10^{7} \mathrm{CFU} / \mathrm{ml}$ & $10^{8} \mathrm{CFU} / \mathrm{ml}$ \\
\hline 100 & $19.2 \pm 0.5 \mathrm{a}$ & $15.5 \pm 0.6 \mathrm{a}$ \\
\hline 50 & $14.1 \pm 0.5 b$ & $9.7 \pm 1.0 \mathrm{~b}$ \\
\hline 25 & $0 \pm 0 \mathrm{c}$ & $0 \pm 0 \mathrm{c}$ \\
\hline Control & $0 \pm 0 \mathrm{c}$ & $0 \pm 0 \mathrm{c}$ \\
\hline
\end{tabular}

y Values are the mean of nine replicates. $\mathrm{SE}=$ standard error. Values within columns followed by different letters are significantly different at $P \leq$ 0.05 according to Tukey's honestly significant difference test.

${ }^{\mathrm{z}}$ Concentration of A. fisulosum extracts (1:1 [wt/vol]); $1 \mathrm{~g}$ of extract diluted in $1 \mathrm{ml}$ of distilled water corresponds to a concentration of $100 \%$. were undetectable 3 days after soil treatment whereas, in soils treated with A. fistulosum extract at concentrations of 50 and $25 \%$, the populations declined to 2.6 and $4.6 \mathrm{log} \mathrm{CFU} / \mathrm{g}$ of dry soil, respectively, 3 days after soil treatment. At 60 days after soil treatment, population densities continued to be undetectable with $A$. fistulosum extract at a concentration of $100 \%$; with A. fistulosum extract at a concentration of $50 \%, R$. solanacearum populations declined from 5.0 to $0.8 \mathrm{log} \mathrm{CFU} / \mathrm{g}$ of dry soil whereas, with $A$. fistulosum extract at a concentration of $25 \%, R$. solanacearum populations remained high (4.3 log CFU/g of dry soil). The initial bacterial population of no RS bacteria in untreated control was undetectable at the beginning of the experiment and increased slightly to reach $0.3 \log$ CFU/g of dry soil after 60 days (Fig. 1B). The effect of A. fistulosum extract on bacterial populations of no RS bacteria was apparent 3 days after soil treatment. With $A$. fistulosum extract at a concentration of $100 \%$, bacterial populations of no RS bacteria increased considerably faster than with extract at other concentrations (50 and 25\%) until reaching $8.0 \mathrm{log}$ CFU/g of dry soil 3 days after soil treatment. In parallel, the no RS bacteria populations in soils treated with A. fistulosum extract at concentra-

A

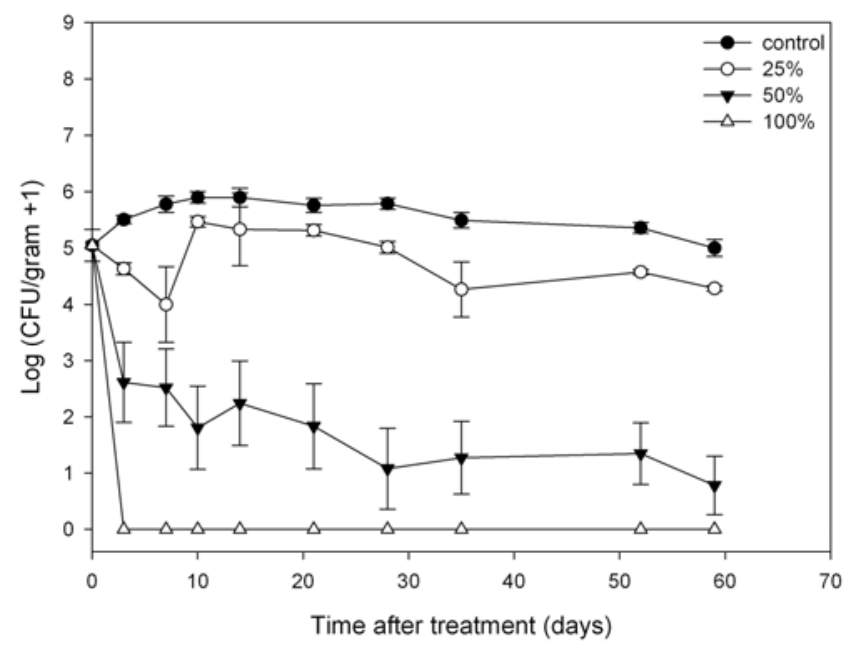

B

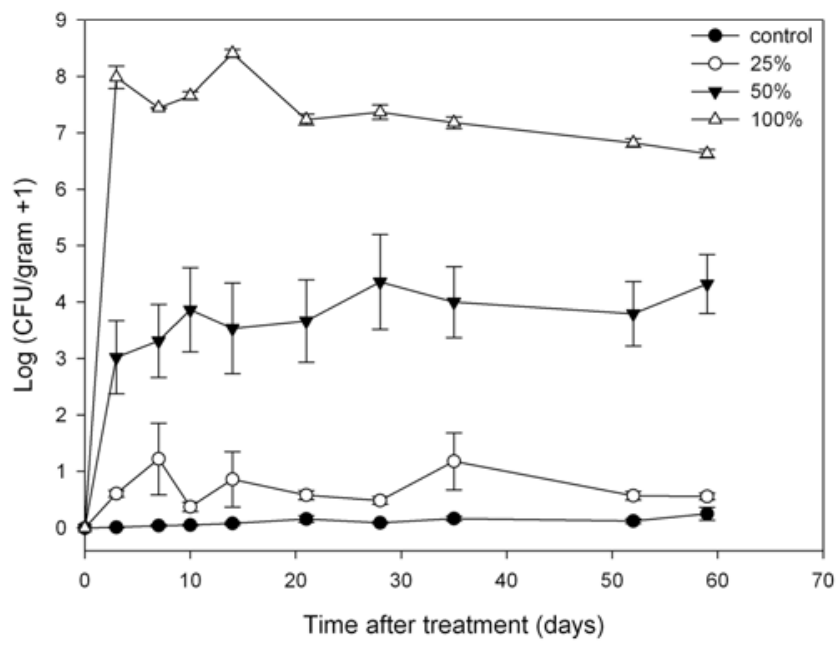

Fig. 1. A, Population of Ralstonia solanacearum phylotype IIB/4NPB and B, bacterial populations other than $R$. solanacearum in artificially infested soil after treatment with different concentrations $(100,50$, and $25 \%$ ) of Allium fistulosum aqueous extracts. Viable cells grown on semi-selective medium (South Africa) are reported as log CFU per gram of dry soil +1 . Infested soil without extract served as control. Each data point is an average of 10 replications. Standard errors are shown by vertical bars. 
tions of 50 and $25 \%$ increased to 3.0 and $0.6 \log$ CFU/g of dry soil, respectively, 3 days after soil treatment. At 60 days after soil treatment, densities of no RS bacteria populations reached $6.6 \mathrm{log}$ $\mathrm{CFU} / \mathrm{g}$ of dry soil with $A$. fistulosum extract at a concentration of $100 \%$; with A. fistulosum extract at a concentration of $50 \%$, bacterial populations increased to $4.3 \log \mathrm{CFU} / \mathrm{g}$ of dry soil whereas, with A. fistulosum extract at a concentration of $25 \%$, populations remained low (0.6 log CFU/g of dry soil).

Experiment 3, disease control. A. fistulosum extracts at concentrations of 100 and $50 \%$ were the most effective in the in vitro and soil population survival studies; therefore, these concentrations were selected for disease assessment. Mixed effects models (Table 2) showed a significant effect of the duration of the preplant treatment, the concentration of the extract, and interaction between these two variables on the incidence of bacterial wilt. The effect of time after transplanting was not significant but the effects of first-

Table 2. Analyses of bacterial wilt incidence by generalized mixed-effect models with binomial error (total of 2,808 samples)

\begin{tabular}{lcccc}
\hline Model $^{\mathbf{z}}$ & df & $\boldsymbol{A I C}$ & $\begin{array}{c}\text { Log- } \\
\text { likelihood }\end{array}$ & $\boldsymbol{P}$ value \\
\hline d, t, c, c:t, d:t, c:d & 9 & 805 & -393 & $\ldots$ \\
-c:t & 8 & 862 & -399 & 0.0005 \\
-d:t & 8 & 813 & -398 & 0.0013 \\
-c:d & 8 & 810 & -397 & 0.0054 \\
d, t, c & 6 & 832 & -410 & $\ldots$ \\
-d & 5 & 1,179 & -586 & $<0.0001$ \\
-t & 5 & 831 & -411 & 0.3548 \\
-c & 5 & 1,634 & -812 & $<0.0001$ \\
Null & 3 & 1,822 & -908 & $\ldots$ \\
\hline
\end{tabular}

All models include two random effects: "plant identifier" and "block". Codes for effects: $\mathrm{d}=$ duration of preplant treatment, $\mathrm{t}=$ time after transplanting, $\mathrm{c}=$ concentration of Allium fistulosum extract. A null model with no variables was included for comparative purposes. The significance of each effect was tested by removing the variable from one of the two complete models. order interactions between this variable and the two others (duration of the preplant treatment and concentration of A. fistulosum extract) on the incidence of bacterial wilt were significant.

Typical bacterial wilt symptoms were observed 5 days after the tomato plants were transplanted (Fig. 2). The cause of the wilt was confirmed to be $R$. solanacearum phylotype IIB/4NPB by isolating the bacterium from wilted plants followed by Pmx-PCR and MmxPCR analysis of the bacterial culture obtained.

A. fistulosum extracts provided effective protection against tomato bacterial wilt. At an extract concentration of $100 \%$, only 6 and $3 \%$ of the plants were wilted at the end of experiment in the 15- and 30-day preplant treatments, respectively, which was significantly less than the untreated control (Fig. 2). A. fistulosum extracts at a concentration of 50\% also significantly reduced the final incidence of bacterial wilt compared with the untreated control; 14 and $11 \%$ of plants were wilted in the 15- and 30-day preplant treatments, respectively. Both concentrations of A. fistulosum extract significantly protected tomato plants from bacterial wilt disease, regardless of the duration of preplant treatment.

At the end of the experiment, no asymptomatic tomato plants were infected at the basal part of the stem, suggesting the absence of latent infections in remaining Heatmaster tomato plants, regardless of the concentration of the A. fistulosum extract and the duration of preplant treatment.

\section{Discussion}

Due to the lack of commercially available resistant cultivars of tomato for the management of diverse plant-pathogenic organisms, including $R$. solanacearum, the use of plant-derived compounds to control bacterial diseases has been the subject of increasing interest $(4,18,19,26)$. Because emerging $R$. solanacearum populations were reported to affect international major resistant sources (23), A. fistulosum-derived extract was evaluated as alternative biocontrol in this study.

In the current study, A. fistulosum extract was found to be effective in reducing $R$. solanacearum growth in an in vitro assay and,

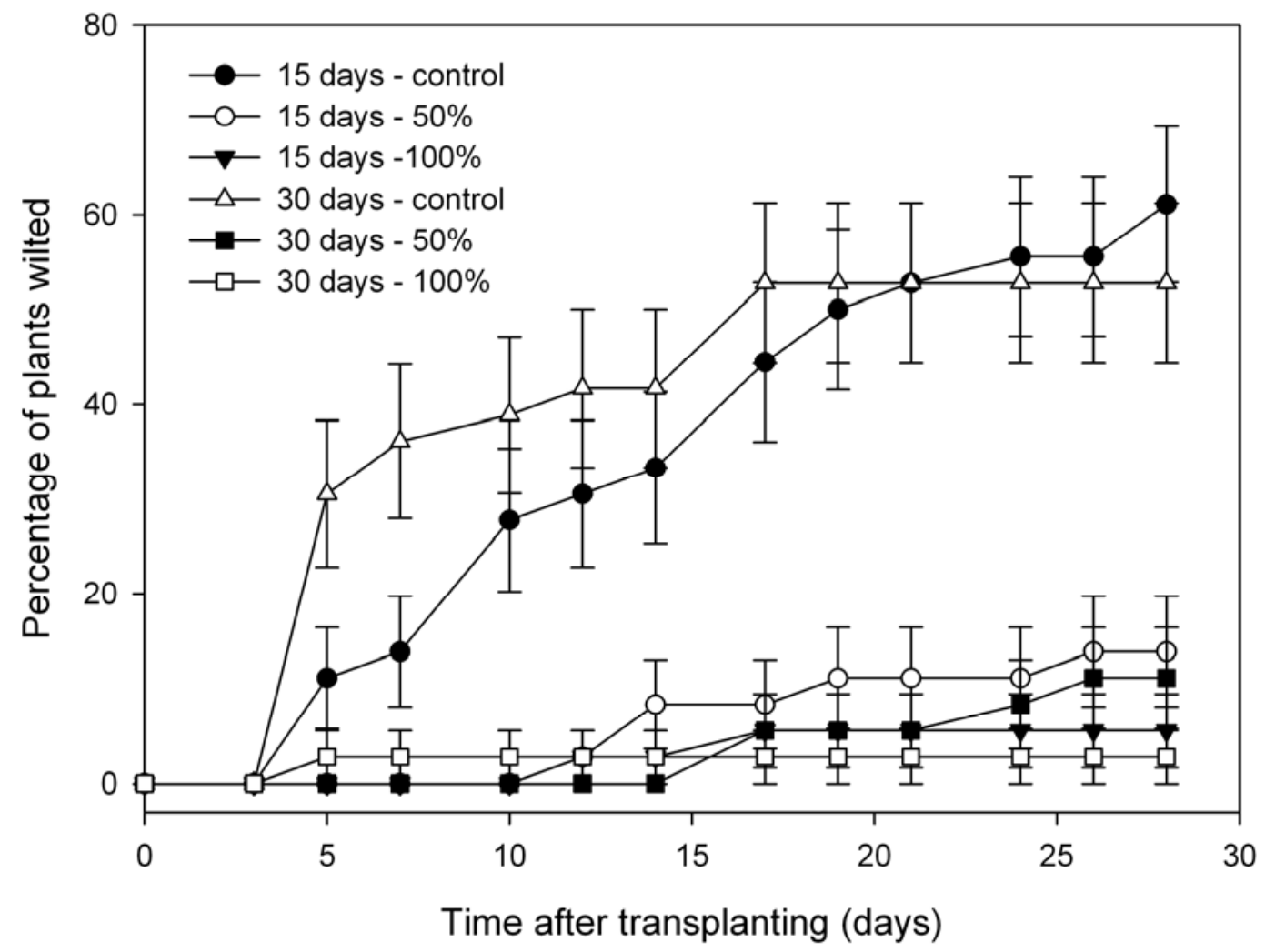

Fig. 2. Incidence of bacterial wilt on tomato 'Heatmaster' with two durations of preplant treatments ( 15 and 30 days) at two concentrations (100 and $50 \%$ ) of Allium fistulosum aqueous extracts. Infested soil without extract served as control. Values in the figure represent means of 36 replicates. Errors bars indicate standard errors of the means. 
also, $R$. solanacearum populations and bacterial wilt incidence of tomato grown in infested soil.

Our studies, based on an in vitro assay using well diffusion, showed the antibacterial properties of A. fistulosum against the highly virulent $R$. solanacearum strain CFBP6783, belonging to the emerging population phylotype IIB/4NPB (experiment 1 ). The antibacterial effect was confirmed in in vivo assays using artificially infested soil. The $R$. solanacearum population decline effect was significant, rapid (3 days), and persistent ( 2 months) independent of the A. fistulosum extract concentration (experiment 2). $R$. solanacearum was not recovered from the soil treated with $A$. fistulosum extract at a concentration of $100 \%$ whereas several tomato plants wilted after transplantation in the same soil treated with A. fistulosum extract at a concentration of $100 \%$ (experiment 3 ). In this case, the pathogen may have survived at very low levels in the soil, making it undetectable by culturing. Residual inoculum was able to infect and colonize roots of tomato but not to any great degree. In the same experiment, growth of no RS bacteria populations on SMSA medium indicate that A. fistulosum extracts might increase microbial activity in the soil. However, no adverse effects were observed and no symptoms from major bacterial diseases developed on tomato plants.

The reduction in the $R$. solanacearum populations in the soil treated with $A$. fistulosum extracts at 100 and $50 \%$ concentrations resulted in a marked decrease in disease incidence on tomato Heatmaster in a growth chamber. Although much of the activity of $A$. fistulosum extracts may be inherent in the active compounds and extract concentration, the duration of preplant treatment determine effectiveness for disease control, as shown in our study.

Our finding that $A$. fistulosum extract greatly reduced $R$. solanacearum in soil within 3 days suggests that it could be used under field conditions with a short period between soil treatment and planting. Although it is expected that $R$. solanacearum populations in most field conditions are not as high as those used in this study, a hindrance to field application of A. fistulosum extract is the huge quantity of fresh plant material required. Thus, large-scale application of $A$. fistulosum extract to treat $R$. solanacearum-infested fields in Martinique is not yet possible considering that at, 100 and $50 \%$ concentrations, 40 and $20 \mathrm{~kg}$ of fresh plant material, respectively, would be needed to treat $1 \mathrm{~m}^{2}$ to a $30-\mathrm{cm}$ depth. To reduce the quantity required, application at field scale could be through drip irrigation lines, as already tested by Ji et al. (19) for application of thymol. However, further studies are needed to optimize the dosage of application to achieve maximum disease control efficacy and economic benefit.

Three different mechanisms may explain the observed disease control by A. fistulosum extracts: (i) direct antimicrobial activity of active compounds contained in the extract or liberated by the extract, (ii) indirect antimicrobial activity induced by the stimulation of antagonistic or competitive microorganisms, and (iii) induction of systemic resistance in host plants resulting in reduction of disease development. The first mechanism is well documented $(3,30)$. Several molecules, including allicin $(9,10)$, have been identified and their antimicrobial properties against a wide range of plant pathogens demonstrated $(12,30,32)$. To demonstrate the bactericidal properties of $A$. fistulosum extract, epifluorescence microscopy has to be performed, as described by Paret et al. (25). Our results suggest that the second mechanism could play a role in the control of bacterial wilt induced by A. fistulosum extract but we were unable to confirm that hypothesis because we used SMSA to evaluate no RS bacteria populations in soil, and this medium only allows certain bacteria to grow. Thus, this hypothesis thus needs to be critically tested using nonselective media such as Levure-peptone-glucose agar (31). The third mechanism, induction of systemic resistance, has already been demonstrated by Hassan et al. (16) in potato plants against bacterial wilt disease by plant extracts. The induction of systemic resistance in tomato against bacterial wilt by A. fistulosum extract can be evaluated using a split-root system or by measuring the activity of defense-related enzymes (16).
Cover cropping followed by mulching of A. fistulosum in order to release active compounds of the crop into pathogen-infested fields is also an interesting approach. With this approach, two additional suppression mechanisms might occur: (i) disruption of the infectious cycle of $R$. solanacearum, leading to a reduction in its population in the soil, and (ii) release of allelopathic compounds in the soil via root exudates of crops with antibacterial properties against $R$. solanacearum, as reported by Yu (38) for A. tuberosum.

A. fistulosum extracts showed promising results in our study. The extract inhibits growth of $R$. solanacearum phylotype IIB/4NPB in vitro. Its application to soil drastically reduced $R$. solanacearum populations and the incidence of tomato bacterial wilt in growthchamber experiments. Plant-derived compounds have the advantage of limited negative impacts on human health and on the environment. Due to the volatile property and broad-spectrum functions of Allium spp., A. fistulosum products could be used in the integrated management of soilborne disease in tomato if an increase in the yield of the tomato crop can be shown. Further studies are also required to determine the effectiveness of A. fistulosum products in the field and to compare cultivars with different levels of sulfur-based volatiles to manage bacterial wilt of tomato.

\section{Acknowledgments}

This research was supported by the European Union (FEDER project) and the Conseil Régional de Martinique. We thank J. M. Risède and K. Lakhia, UPR "Systèmes de culture bananiers", CIRAD Guadeloupe, for providing freezedried aqueous extract of A. fistulosum; and G. M. Balestra, Dipartimento di Scienze e Tecnologie per l'Agricoltura, le Foreste, la Natura e l'Energia (DAFNE), Universita degli Studi della Tuscia, Italy, for the critical reading of the manuscript.

\section{Literature Cited}

1. Abdel-Monaim, M. F., Abo-Elyousr, K. A. M., and Morsy, K. M. 2011. Effectiveness of plant extracts on suppression of damping-off and wilt disease of lupine (Lupinus termis Forsik). Crop Prot. 30:185-191.

2. Abo-Elyousr, K. A. M., and Asran, M. R. 2009. Antibacterial activity of certain plant extracts against bacterial wilt of tomato. Arch. Phytopathol. Plant Prot. 42:573-578.

3. Auger, J., Arnault, I., Diwo-Allain, S., Ravier, M., Molia, F., and Pettiti, M. 2004. Insecticidal and fungicidal potential of Allium substances as biofumigants. Agroindustria 3:5-8.

4. Balestra, G. M., Heydari, A., Ceccarelli, D., Ovidi, E., and Quattrucci, A. 2009. Antibacterial effect of Allium sativum and Ficus carica extracts on tomato bacterial pathogens. Crop Prot. 28:807-811.

5. Bates, D., Maechler, M., and Bolker, B. M. 2011. lme4: Linear mixed-effects models using S4 classes, R package version 0.999375-39. Online publication. http://cran.r-project.org/web/packages/lme4/index.html.

6. Bolker, B. M., Brooks, M. E., Clark, C. J., Geange, S. W., Poulsen, J. R., Stevens, M. H. H., and White, J.-S. S. 2009. Generalized linear mixed models: a practical guide for ecology and evolution. Trends Ecol. Evol. 24:127135.

7. Boscher, J., Auger, J., Mandon, N., and Ferary, S. 1995. Qualitative and quantitative comparison of volatile sulphides and flavour precursors in different organs of some wild and cultivated garlics. Biochem. Syst. Ecol. 23:787-791.

8. Bowers, J. H., and Locke, J. C. 2004. Effect of formulated plant extracts and oils on population density of Phytophthora nicotianae in soil and control of Phytophthora blight in the green house. Plant Dis. 88:11-16.

9. Cavallito, C. J., and Bailey, H. J. 1944. Allicin, the antibacterial principle of Allium sativum. I. Isolation, physical properties and antibacterial action. J. Am. Chem. Soc. 66:1950-1951.

10. Cavallito, C. J., Buck, J. S., and Suter, C. M. 1944. Allicin, the antibacterial principle of Allium sativum. II. Determination of the chemical structure. J. Am. Chem. Soc. 66:1952-1954.

11. Crawley, M. J., ed. 2007. The R Book. John Wiley \& Sons, Ltd, Chichester, UK.

12. Curtis, H., Noll, U., Störmann, J., and Slusarenko, A. J. 2004. Broad spectrum activity of the volatile phytoanticipin allicin in extracts of garlic against plant pathogenic bacteria, fungi and oomycetes. Physiol. Mol. Plant Pathol. 65:79-89.

13. Engelbrecht, M. C. 1994. Modification of a semi-selective medium for the isolation and quantification of Pseudomonas solanacearum. ACIAR, Bacterial Wilt Newsl. 10:3-5.

14. Hanson, P. M., Wang, J.-F., Licardo, O., Hanudin, Mah, S. Y., Hartman, G. L., Lin Y.-C., and Chen J.-T. 1996. Variable reaction of tomato lines to bacterial wilt evaluated at several locations in Southeast Asia. HortScience 31:143-146.

15. Harris, J. C., Cottrell, S. L., Plummer, S., and Lloyd, D. 2001. Antimicrobial properties of Allium sativum (garlic). Appl. Microbiol. Biotechnol. 
57:282-286.

16. Hassan, M. A. E., Bereika, M. F. F., Abo-Elnaga, H. I. G., and Sallam M. A. A. 2009. Direct antimicrobial activity and induction of systemic resistance in potato plants against bacterial wilt disease by plant extracts. Plant Pathol. J. 25:352-360.

17. Hayward, A. C. 1991. Biology and epidemiology of bacterial wilt caused by Pseudomonas solanacearum. Annu. Rev. Phytopathol. 29:65-87.

18. Ji, P., Momol, M. T., Olson, S. M., Pradhanang, P. M., and Jones, J. 2005. Evaluation of thymol as biofumigant for control of bacterial wilt of tomato under field conditions. Plant Dis. 89:497-500.

19. Ji, P., Momol, M. T., Rich, J. R., Olson, S. M., and Jones, J. B. 2007. Development of an integrated approach for managing bacterial wilt and root-knot nematodes on tomato under field conditions. Plant Dis. 91:1321-1326.

20. Jourand, P., Rapior, S., Fargette, M., and Mateille, T. 2004. Nematostatic activity of aqueous extracts of West African Crotalaria species. Nematology 6:765-771.

21. Kagale, S., Marimuthu, T., Thayumanavan, B., Nandakumar, R., and Samiyappan, R. 2004. Antimicrobial activity and induction of systemic resistance in rice by leaf extract of Datura metel against Rizoctonia solani and Xanthomonas oryzae pv. Oryzae. Physiol. Mol. Plant Pathol. 65:91-100.

22. Kelman, A. 1954. The relationship of pathogenicity in Pseudomonas solanacearum to colony appearance on a tetrazolium medium. Phytopathology 44:693-695.

23. Lebeau, A., Daunay, M. C., Frary, A., Palloix, A., Wang, J. F., Dintinger, J., Chiroleu, F., Wicker, E., and Prior, P. 2011. Bacterial wilt resistance in tomato, pepper, and eggplant: genetic resources respond to diverse strains in the Ralstonia solanacearum species complex. Phytopathology 101:154-165.

24. McCullagh, P., and Nelder, J. A. 1989. Generalized Linear Models. Chapman and Hall, London.

25. Paret, M. L., Cabos, R., Kratky, B. A., and Alvarez, A. M. 2010. Effect of plant essential oil on Ralstonia solancearum race 4 and bacterial wilt of edible ginger. Plant Dis. 94:521-527.

26. Pradhanang, P. M., Momol, M. T., Olson, S. M., and Jones, J. B. 2003. Effects of plant essential oils on Ralstonia solanacearum population density and bacterial wilt incidence in tomato. Plant Dis. 87:423-427.

27. Prior, P., and Fegan, M. 2005. Diversity and molecular detection of Ralstonia solanacearum race 2 strains by multiplex PCR. Pages 405-414 in: Bacterial Wilt Disease and the Ralstonia solanacearum Species Complex.
C. Allen, P. Prior, and A. C. Hayward, eds. American Phytopathological Society, St. Paul, MN.

28. Prior, P., and Steva, H. 1990. Characteristics of strains of Pseudomonas solanacearum from the French West Indies. Plant Dis. 74:13-17.

29. R Development Core Team. 2010. R: A Language and Environment for Statistical Computing. R Foundation for Statistical Computing, Vienna.

30. Regnault Roger, C., Philogène, B. J. R., and Vincent, C. 2005. Biopesticides of Plant Origin. Lavoisier, Paris.

31. Schaad N. W., Jones J. B., and Chun W. 2001. Laboratory Guide for Identification of Plant-Pathogenic Bacteria, 3rd ed. American Phytopathological Society, St. Paul, MN.

32. Slusarenko, A. J., Patel, A., and Portz, D. 2008. Control of plant disease by natural products: allicin from garlic as a case study. Eur. J. Plant Pathol. 121:313-322.

33. Teng, Y., Yang, G., Yu, Z., Zhou, G., Sun, G., Jin, H., and Hou, T. 2010. In vitro antimicrobial activity of the leaf essential oil of spiraea alpina Pall. World J. Microbiol. Biotechnol. 26:9-14.

34. Van Elsas, J., and Smalla, K. 1997. Methods for sampling soil microbes. Pages 383-390 in: Manual of Environmental Microbiology. C. J. Hurst, G. R. Knudsen, M. J. McInerney, C. H. Stetzenbach, and M. V. Walter, eds. American Society for Microbiology Press, Washington, DC.

35. Wicker, E., Coranson-Beaudu, R., Cadasse, S., and William, M.-A. 2009. Emerging strains of Ralstonia solanacearum in the French West Indies raise new challenges to tomato breeders. Acta Hortic. 808:279-286.

36. Wicker, E., Grassart, L., Coranson-Beaudu, R., Mian, D., Guilbaud, C., Fegan, M., and Prior, P. 2007. Ralstonia solanacearum strains from Martinique (French west Indies) exhibiting a new pathogenic potential. Appl. Environ. Microbiol. 73:6790-6801.

37. Wicker, E., Grassart, L., Coranson-Beaudu, R., Mian, D., and Prior, P. 2009 Epidemiological evidence for the emergence of a new pathogenic variant of Ralstonia solanacearum in Martinique (French West Indies). Plant Pathol. 58:853-861.

38. Yu, J. Q. 1999. Allelopathic suppression of Pseudomonas solanacearum infection of tomato (Lycopersicon esculentum) in a tomato-chinese chive (Allium tuberosum) intercropping system. J. Chem. Ecol. 25:2409-2417.

39. Zuur, A. F., Ieno, E. N., Walker, N. J., Saveliev, A. A., and Smith, G. M 2009. Mixed Effects Models and Extensions in Ecology with R. Springer Science + Business Media, New York. 